\title{
Botryosphaeriaceae Species Spore-Trapping Studies in California Vineyards
}

J. R. Úrbez-Torres, Department of Plant Pathology, University of California, Davis 95616; M. Battany, University of California Cooperative Extension, San Luis Obispo County, San Luis Obispo 93401; L. J. Bettiga, University of California Cooperative Extension, Monterey County, Salinas 93901; C. Gispert, University of California Cooperative Extension, Riverside County, Indio 92201; G. McGourty, University of California Cooperative Extension, Mendocino County, Ukiah 95482; J. Roncoroni, University of California Cooperative Extension, Napa County, Napa 94559; R. J. Smith, University of California Cooperative Extension, Sonoma County, Santa Rosa 95403; P. Verdegaal, University of California Cooperative Extension, San Joaquin County, Stockton 95206; and W. D. Gubler, Department of Plant Pathology, University of California, Davis

\begin{abstract}
Úrbez-Torres, J. R., Battany, M., Bettiga, L. J., Gispert, C., McGourty, G., Roncoroni, J., Smith, R. J., Verdegaal, P., and Gubler, W. D. 2010. Botryosphaeriaceae species spore-trapping studies in California vineyards. Plant Dis. 94:717-724.

The seasonal abundance of Botryosphaeriaceae spp. spores was studied in California vineyards by using glass microscope slides covered with petroleum jelly placed on grapevine cordons and Burkard volumetric spore traps at seven and two different locations, respectively. Correlation analysis was used to determine which meteorological variables (precipitation, relative humidity, temperature, and wind speed) influenced Botryosphaeriaceae spp. spore release. Among all variables, regression analysis resulted in a strong relationship between spore release and precipitation. Additionally, a positive relationship between irrigation and spore release was also observed in the Riverside County vineyard. During the study period, spore discharge of Botryosphaeriaceae spp. occurred from the first fall rain through the last spring rains, coinciding with September to April. However, based on the results obtained from the spore traps, most spores (over 60\%) were trapped following rain events during the winter months of December, January, and February, which coincides with the grapevine pruning season. Botryosphaeriaceae spp. spore release was much lower in fall and early spring (22\%) and very few or no spores were trapped in late spring and summer (3\%). This work suggests that a delay of pruning time in California may be warranted to reduce grapevine infection because the current timing coincides with the greatest period of spore discharge.
\end{abstract}

Fungal species in the family Botryosphaeriaceae are cosmopolitan endophytes, pathogens, and saprophytes on a diverse range of dicots, gymnosperms, and monocots $(2,27,42)$. Although long known as vascular pathogens causing canker diseases and dieback in numerous woody perennial hosts (41), species of Botryosphaeriaceae have only recently been recognized as important pathogens of grapevines (Vitis vinifera L.) $(29,35,36,41)$. To date, 15 different members of the Botryosphaeriaceae family, placed in the anamorphic genera Diplodia, Dothiorella, Fusicoccum, Lasiodiplodia, and Neofusicoccum, have been reported to be pathogenic on grapevines and to cause different grapevine dieback symptoms worldwide $(29,34,37,39,41)$. Grapevine diseases caused by species of Botryosphaeriaceae include black dead arm (11),

Corresponding author: W. D. Gubler

E-mail: wdgubler@ucdavis.edu

Accepted for publication 16 February 2010.

doi:10.1094/PDIS-94-6-0717

(C) 2010 The American Phytopathological Society bot canker (10,36), Diplodia cane dieback (7), excoriose (19), and macrophoma rot (13).

In California, Botryosphaeriaceae spp. have been reported to be the most prevalent fungi isolated from grapevine cankers, and nine specific fungi are known to be responsible for one particular disease known as bot canker $(10,35,38,39)$. Symptoms of the disease are characterized by dead cordons, spurs, and trunks, and the total absence of spring growth due to canker formation in the vascular tissue $(10,38)$. In general, cankers are wedge shaped, typically begin in pruning wounds, and primarily grow basipetally from the initial point of infection $(6,38)$. Dark vascular streaking of the wood is also commonly observed in grapevines infected by species of Botryosphaeriaceae such as the pathogens Botryosphaeria dothidea, Lasiodiplodia theobromae, and Neofusicoccum parvum in California $(35,38,39)$. Members of the Botryosphaeriaceae family have been reported to cause bot canker in grapegrowing regions of Australia (4,29), Chile (9), Mexico (36), and Spain (40) and in Arizona, Arkansas, Connecticut, Maryland, Massachusetts, Missouri, Nevada, New Hampshire, New York, Oregon,
Pennsylvania, Rhode Island, Texas, Vermont, and Virginia in the United States $(23,34,37)$.

Grapevine trunk disease pathogens infect grapevines primarily through pruning wounds. Previous studies carried out in California have reported that inoculum of Phaeomoniella chlamydospora and Phaeoacremonium spp., the causal agents of petri disease and esca, respectively, as well as Eutypa lata and E. leptoplaca, the causal agents of eutypa dieback, are airborne following rainfall events and typically enter grapevines from late fall through early spring $(5,18,21,32,33)$. However, little is known about the epidemiology and mode of inoculum dispersal of Botryosphaeriaceae spp. on grapevines. Bot canker (along with eutypa dieback) is responsible for important economic losses to the California grapevine industry, which are estimated to be over $\$ 260$ million annually (26). Knowledge of Botryosphaeriaceae spp. inoculum availability during timing of inoculum dispersal, as well as the environmental factors that favor spore release, is critical to determine periods of low infection risk and, therefore, potential preventative measures, including appropriate timing for pruning and pruning wound treatments. The purpose of this study was to determine when and under what environmental conditions spores of Botryosphaeriaceae spp. are released in California vineyards.

\section{MATERIALS AND METHODS}

Glass microscope slide spore trapping. Glass microscope slides provided a rapid and easy means of quantifying spores from within vineyards. Spore traps consisted of glass microscope slides ( 25 by 76 $\mathrm{mm}$ ) coated on both sides with a thin layer of white petroleum jelly and placed on grapevine cordons at approximately $80 \mathrm{~cm}$ above the ground as described by Eskalen and Gubler (5) (Fig. 1a). Traps were placed in seven different vineyards where bot canker had previously been reported to occur by field surveys $(38,39)$. Vineyards were located throughout the major grapegrowing regions of California, including Mendocino and Napa Counties in the North Coast, Colusa County in the Sacra- 
mento Valley, San Joaquin County in the north San Joaquin Valley, Monterey and San Luis Obispo Counties in the Central Coast, and Riverside County in Southern California (Fig. 1b). Ten spore traps were placed randomly on separate vines in the middle of a block (each block contained at least 45 rows of vines) in each vineyard. Spore traps were changed weekly and individually collected in preautoclaved 50ml screw-cap tubes (Sarstedt, Inc., Newton, NC) and sent to the laboratory. Spores were removed by adding $10 \mathrm{ml}$ of approximately $20^{\circ} \mathrm{C}$ distilled water into the screw-cap tube and then shaken by hand for $60 \mathrm{~s}$. Two aliquots of $200 \mu \mathrm{l}$ each were collected per spore trap and placed on two replicate 85 -mm-diameter petri plates containing potato dextrose agar (PDA; Difco Laboratories, Detroit) amended with tetracycline hydrochloride $(0.01 \%$; SigmaAldrich, St. Louis) (PDA-tet). The liquid solution was spread over the petri plates using a sterilized curved glass rod and plates were dried for $10 \mathrm{~min}$ inside a laminar flow hood. Petri plates were incubated on the laboratory bench at room temperature $\left(25 \pm 1^{\circ} \mathrm{C}\right)$ and Botryosphaeriaceae fungal colonies were recorded after 7 days (Fig. 1d and e). Botryosphaeriaceae colonies were subcultured onto fresh PDA-tet in an attempt to morphologically identify to genus or species level. Spore-trapping studies were conducted from September 2006 through May 2009 in Napa, San Joa-
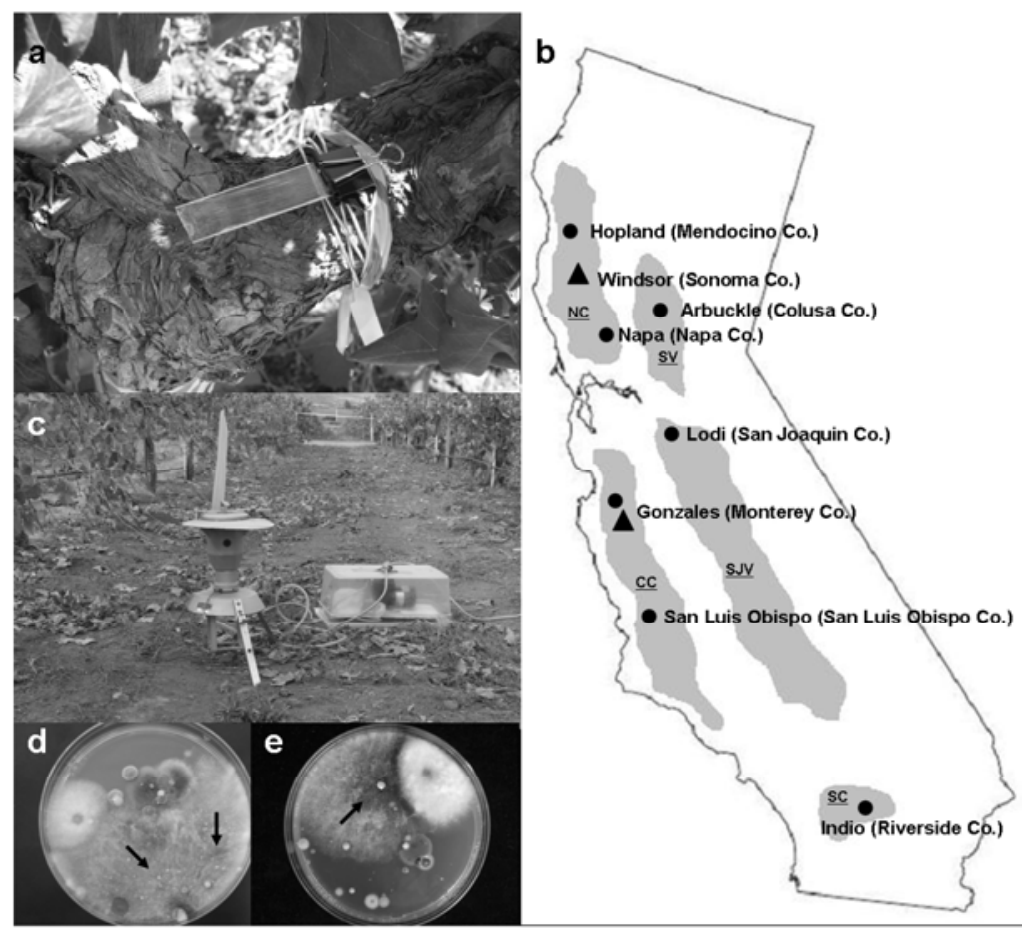

Fig. 1. a, Glass microscope slide spore trap coated in both sides with white petroleum jelly on a grapevine cordon. b, Botryosphaeriaceae spore-trapping vineyard sites throughout California $(\bullet=$ microscope glass slide spore traps and $\boldsymbol{\Delta}=$ Hirst-Burkard volumetric spore trap). NC: north coast, SV: Sacramento Valley, SJV: San Joaquin Valley, CC: Central Coast, SC: Southern California grape-growing regions. c, Hirst-Burkard volumetric spore trap placed in Monterey County. d and e, Black arrows show d, Lasiodiplodia theobromae colonies from Indio (Riverside County) and e, Diplodia seriata colonies from Napa County growing on potato dextrose agar amended with tetracycline hydrochloride.
(31). Species spores of Botryosphaeriaceae were identified based on morphological characters (shape, size, color, and absence or presence of septa) as previously described $(20,38)$.

Environmental monitoring and data analysis. Total number of Botryosphaeriaceae spores captured from glass microscope slides and Burkard volumetric spore traps was recorded weekly and hourly during the study period, respectively. Results were superimposed with weekly and hourly records of total precipitation, average temperature, average relative humidity, and average wind speed. Weekly values were obtained by the sum of daily precipitation and by averaging daily mean temperature, daily mean relative humidity, and daily mean wind speed. Meteorological data were collected from weather stations within or adjacent to vineyard sites. Offsite weather stations were a part of the California Irrigation Management Information System, Department of Water Resources, Office of Water Use Efficiency. Hourly values were obtained from the private weather stations (Adcon International Inc., Davis, CA) located within the vineyard where the Burkard volumetric spore traps were placed and programmed to read sensors at 15-min intervals and to record average values at 1 -h intervals. Weekly and daily total numbers of Botryosphaeriaceae spp. spores were correlated with the environmental variables recorded on the same week or day at each location by using simple linear regression analysis in PROC GLM in SAS 9.1 (SAS Institute, Cary, NC). In addition, a correlation analysis was performed to determine the correlation between overhead sprinkler irrigation and spore release at the Riverside County vineyard.

\section{RESULTS}

Glass microscope slide spore trapping. Regression analysis indicated a positive relationship between spore release and precipitation $\left(r^{2}=0.7 ; P<0.0001 ; n=\right.$ 847) (Fig. 2) and, as precipitation increased, so did spore release. Weekly relative humidity averages and spore release were also positively correlated $\left(r^{2}=0.08\right.$; $P<0.0001 ; n=847$; data not presented). Overall results present a yearly pattern of Botryosphaeriaceae spp. spore release coinciding with rain events that follow the dry summer period. Spores were captured from September to October through March to April following rainfall events at all locations (Figs. 3 and 4) and also by overhead sprinkler irrigation in the Monterey and Riverside vineyards (Figs. 3B and 4D). At the Riverside location, Botryosphaeriaceae spp. spores were first trapped the third week of September in 2006, the first week of October in 2007, and the third week of October in 2008, which coincided with the first day of the overhead sprinkler irrigation schedule for 
each respective year. Botryosphaeriaceae spp. spores were subsequently captured every week during that period (Fig. 4D). Regression analysis indicated a positive relationship between spore release and irrigation $\left(r^{2}=0.49 ; P<0.0001 ; n=141\right.$; data not presented) at the Riverside County vineyard.

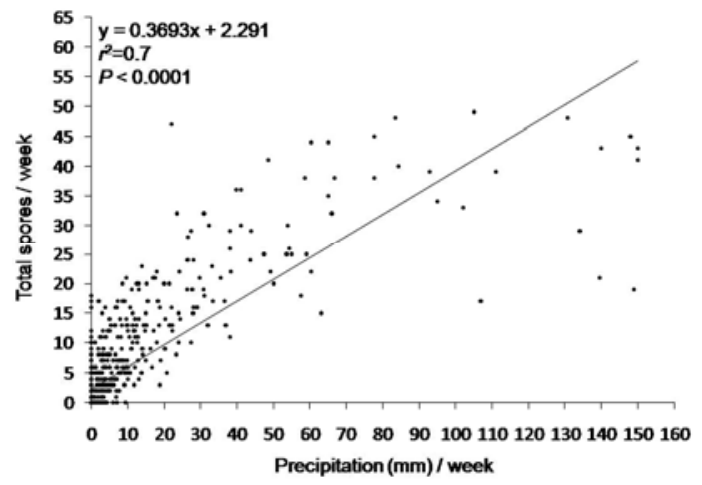

Fig. 2. Scatter plot of the relationship between total spores trapped per week using glass microscope slides and precipitation. Linear regression line and equation are also shown.

Although Botryosphaeriaceae spp. spores were generally trapped from midfall to early spring, the total number of spores trapped varied depending on the season. Glass microscope slides detected the greatest number of Botryosphaeriaceae spp. spores $(68.9 \%)$ to have been trapped during the winter months of December, January, and February from all seven locations. Botryosphaeriaceae spp. spore release was lower $(30.1 \%)$ in fall and early spring than in winter, and very few or no spores $(1 \%)$ were trapped in late spring and summer (May through September) (Figs. 3 and 4).

Regarding the different Botryosphaeriaceae spp. spore types trapped, colony and spore morphological characteristics allowed us to identify five isolates to species (B. dothidea, Diplodia seriata, D. mutila, L. theobromae, and N. parvum) and one to genus level (Dothiorella). The incidence
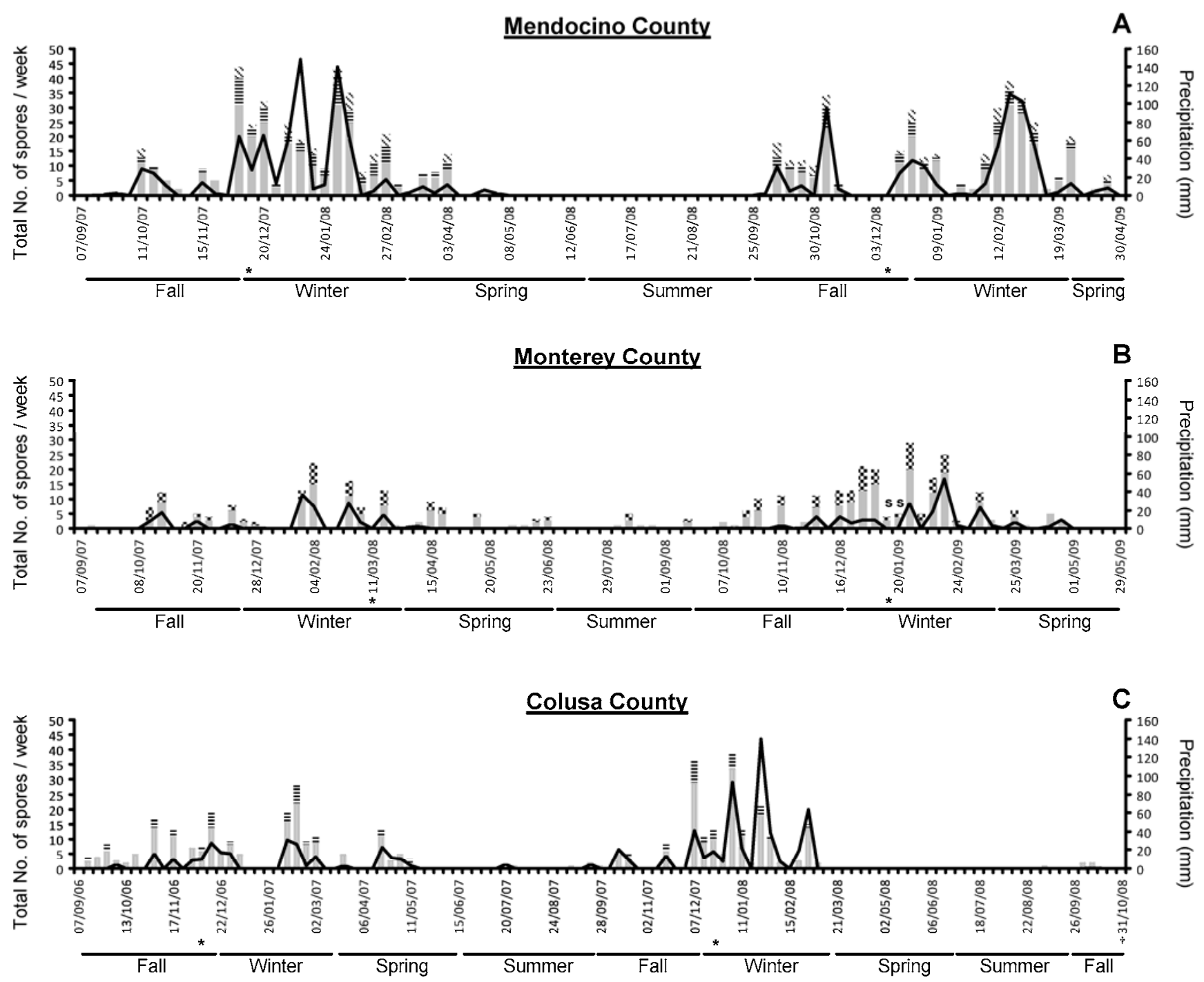

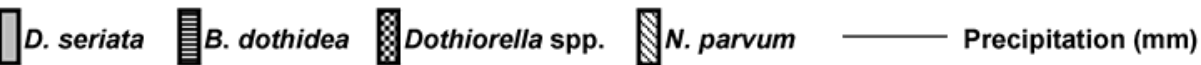

Fig. 3. Total number of Botryosphaeriaceae spores trapped per week using glass microscope slides and rainfall in A, Mendocino; B, Monterey; and C, Colusa Counties. Symbols: $*=$ pruning dates, $\mathrm{s}=$ overhead sprinkler irrigation, and $\dagger=$ vineyard removed. 
and distribution of species of Botryosphaeriaceae varied by the geographic region. D. seriata spores were trapped in all vineyards studied and were the most abundant (59\% of the total spores trapped). Species of Dothiorella (15\% of the total Botryosphaeriaceae spp. spores trapped), followed $D$. seriata in incidence and were only trapped at the vineyard sites located in the Central and North Coast; however, none were trapped at the Mendocino site. $B$. dothidea spores $(9.8 \%$ of the total Botryosphaeriaceae spp. spores trapped) were trapped at the North Coast, Sacramento Valley, and northern San Joaquin Valley
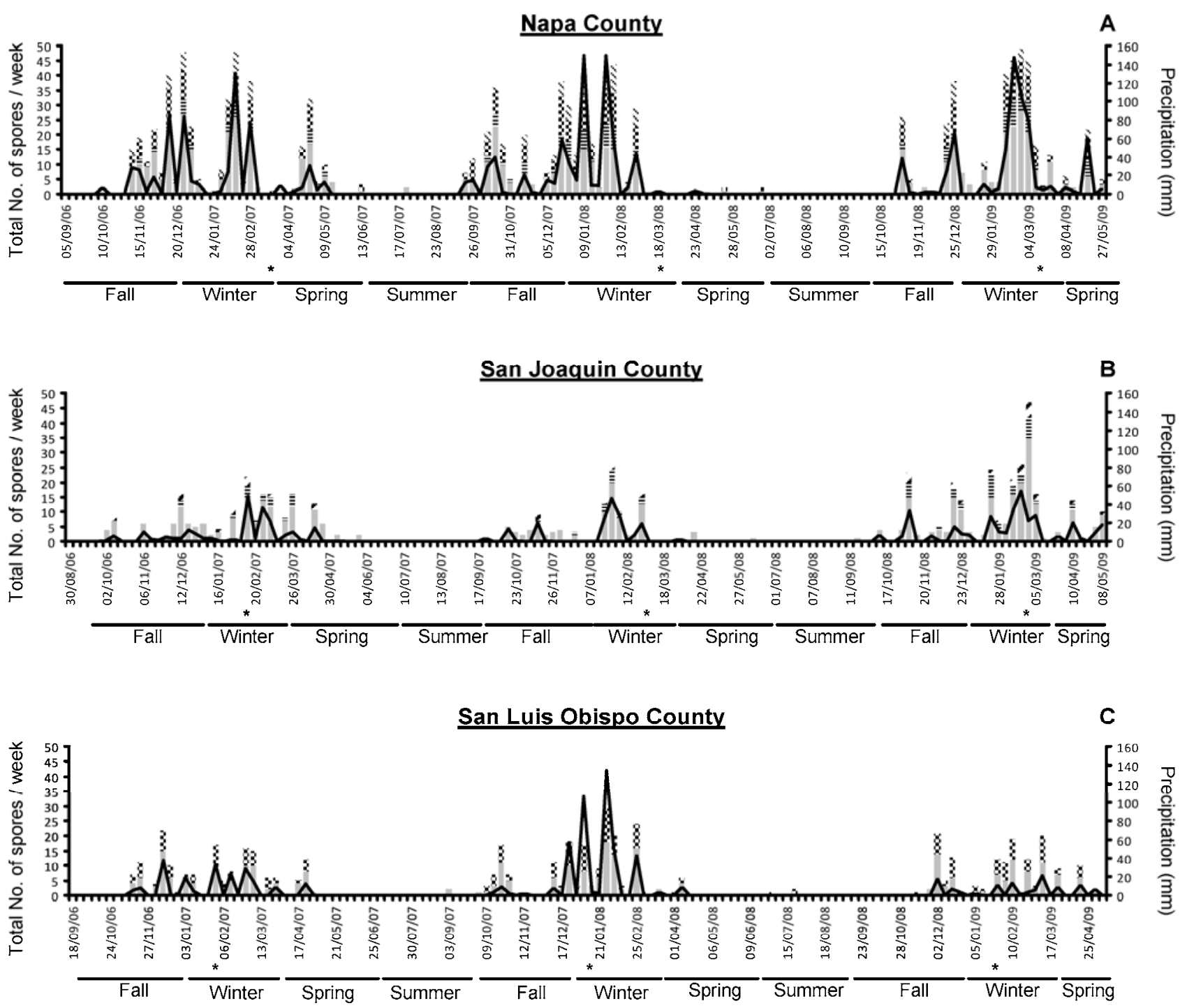

\section{Riverside County}

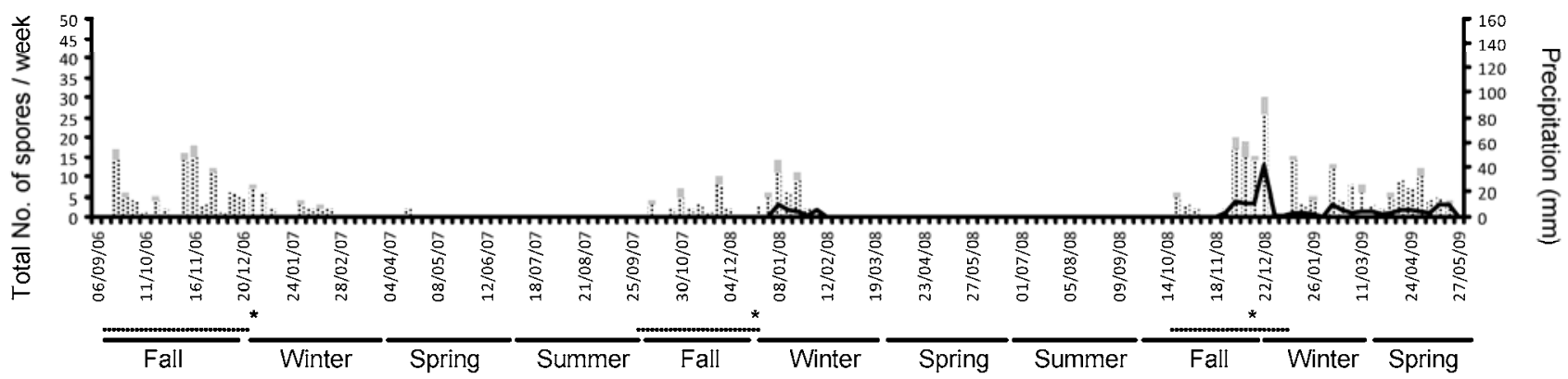

D. seriata 自B. dothidea QDothiorella spp. $\mathbb{N}_{N}$. parvum D. mutila

Fig. 4. Total number of Botryosphaeriaceae spores trapped per week using glass microscope slides and rainfall in A, Napa; B, San Joaquin; C, San Luis Obispo; and D, Riverside Counties. Dotted line under x axis shows daily overhead sprinkler irrigation period at the Riverside vineyard $\left(8 \mathrm{~h}\right.$ day ${ }^{-1}$ and 34 liters $\left.\mathrm{h}^{-1}\right) *^{*}=$ pruning dates. 
vineyards. L. theobromae spores $(9.6 \%$ of the total Botryosphaeriaceae spp. spores trapped) were only trapped at the vineyard in Riverside County in Southern California
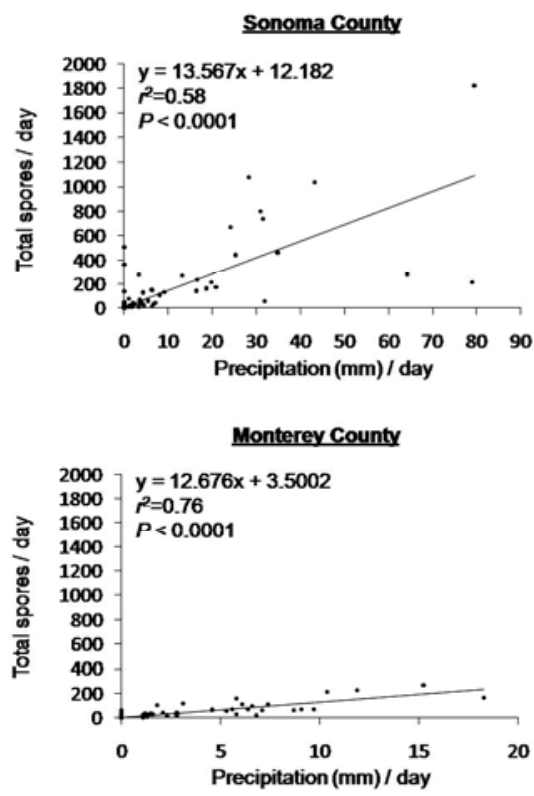

Fig. 5. Scatter plot of the relationship between total spores trapped per day using a Burkard volumetric spore trap and precipitation in Monterey and Sonoma vineyards. and were the most abundant spore type trapped at that location ( $88 \%$ of the total spores trapped). D. mutila and N. parvum were the least abundant spores trapped (1 and $5.6 \%$ of the total Botryosphaeriaceae spp. spores trapped, respectively) and were restricted to vineyards located in the North Coast and northern San Joaquin Valley, respectively.

Volumetric spore trapping. Regression analysis indicated a positive relationship between spore release and precipitation at the Sonoma $\left(r^{2}=0.58 ; P<0.0001 ; n=\right.$ 191) and Monterey $\left(r^{2}=0.76 ; P<0.0001\right.$; $n=152$ ) vineyards (Fig. 5). A daily summary of Botryosphaeriaceae spp. spores trapped at the Monterey and Sonoma vineyard sites from 1 December 2008 through 1 May 2009 and from 1 November 2008 through 8 May 2009, respectively, is represented in Figure 6. The daily total of Botryosphaeriaceae spp. spores was obtained by summation of the spores trapped hourly per $0.6 \mathrm{~m}^{3}$ of air per day. Botryosphaeriaceae spp. spores were released at both vineyard sites after at least $2 \mathrm{~mm}$ of rainfall (Fig. 6). Botryosphaeriaceae spp. spore release was also triggered by overhead sprinkler irrigation at the Sonoma vineyard on both 26 and 27 February 2009 (Fig. 7C). Overhead sprinkler irrigation was used on those dates to lower the level of the reservoir following a period of high rainfall. Sprinkler irrigation was also used at the Sonoma vineyard on 23 March and on 4, 5, 16, 26, 28, and 29 April 2009 for frost protection but no significant amount of Botryosphaeriaceae spp. spores were captured during 26 and 27 February 2009 (Fig. 6B). High numbers of Botryosphaeriaceae spp. spores were first trapped on 14 December 2008 and 1 November 2008 at the Monterey and Sonoma sites, respectively. Botryosphaeriaceae spp. spores were then successfully trapped during each rain event at each location until the end of the study (Fig. 6). Botryosphaeriaceae spp. spores were last trapped on 7 April and 2 May 2009 at Monterey and Sonoma County, respectively, which coincided with the last rain event of the season at both sites. The highest number of Botryosphaeriaceae spp. spores were trapped in February at the Monterey (50.4\%) and Sonoma (65\%) vineyard sites, which coincided with the maximum amount of precipitation for both sites during the study period (Fig. 6). In the Monterey vineyard, $16.1 \%$ of the total spores captured were trapped in December, $24.1 \%$ in January, $8.1 \%$ in March, and $1.3 \%$ in April. In the Sonoma vineyard, $3.8 \%$ of the total spores captured were trapped in November, $19.5 \%$ in December, $1 \%$ in January, $9.8 \%$ in March,
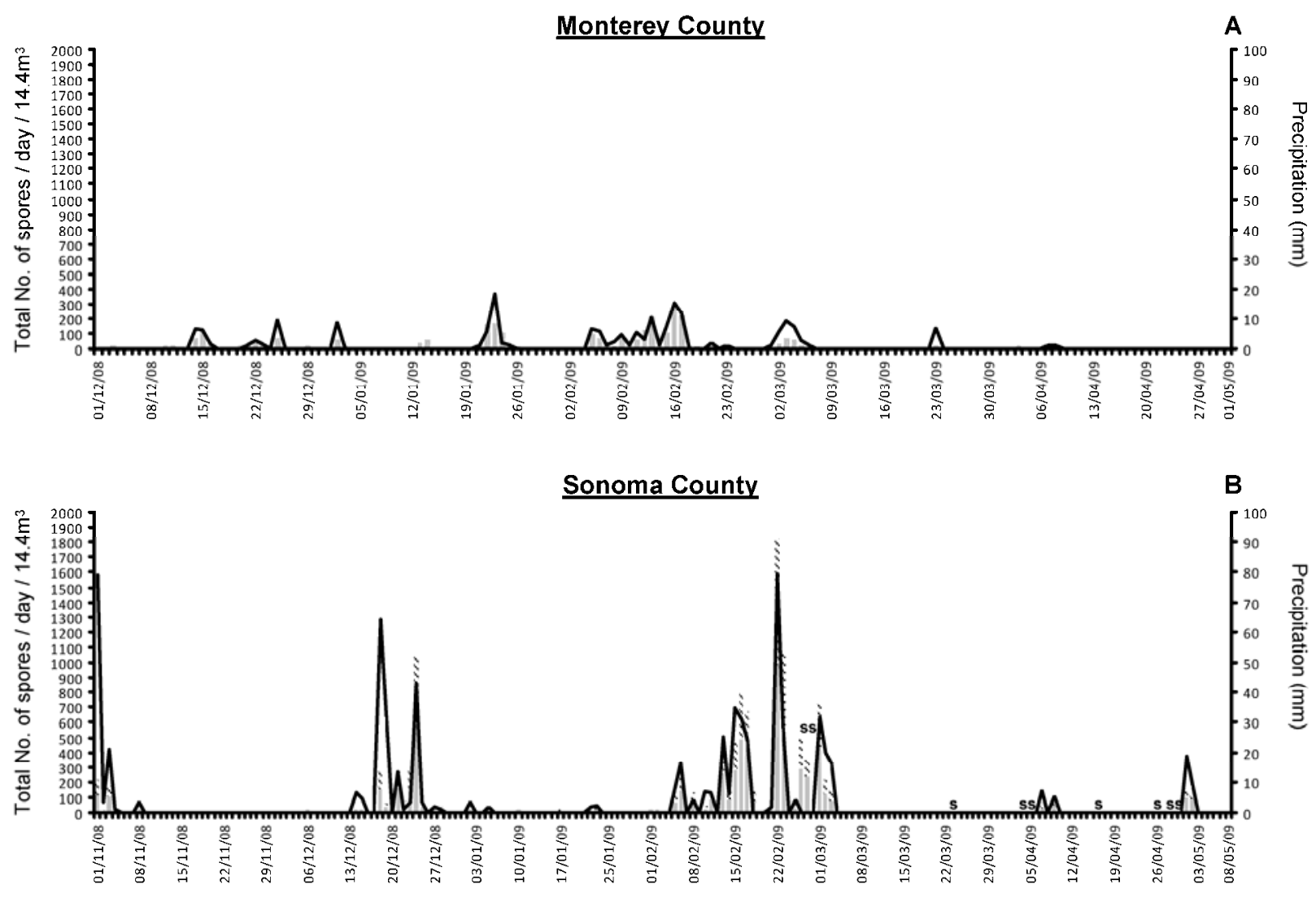

Diplodia spp. I Dothiorella spp. $\quad$ Eusicoccum I Neofusicoccum spp. _ Precipitation (mm)

Fig. 6. Rainfall and total number of Botryosphaeriaceae spores detected daily by sampling $0.6 \mathrm{~m}^{3}$ of air each hour with a Burkard spore trap in A, Monterey and $\mathbf{B}$, Sonoma Counties; $\mathrm{s}=$ overhead sprinkler irrigation. 
and $0.9 \%$ in April. Results of our trapping studies indicated that Sonoma had the greatest amount of inoculum throughout the duration of the study. Botryosphaeriaceae spp. spores triggered by both rainfall and overhead irrigation usually began to appear less than $1 \mathrm{~h}$ after rainfall or irrigation started, continued through the wet period, and ceased after rainfall or irrigation ended (Fig. 7A-C). Botryosphaeriaceae spp. spores were not usually trapped more than 2 $\mathrm{h}$ after rainfall or irrigation ended.

\section{DISCUSSION}

Grapevine trunk diseases in California primarily include bot canker, esca, eutypa dieback, and petri disease $(10,15,25,38)$. Spore-trapping studies previously conducted in vineyards in Australia and in California, Michigan, and New York in the United States showed that E. lata ascospores spread as airborne inoculum during and immediately following rainfall events $(3,14,17,21,31,33)$. Furthermore, similar studies have also demonstrated that spores of P. chlamydospora, Phaeoacremonium aleophilum, and $P$. inflatipes are released during and following rain events throughout the year in California $(5,24)$. Results of our study conclusively demonstrated that Botryosphaeriaceae spp. spores are also released during rainfall and irrigation events throughout the different grapevinegrowing regions.

California weather conditions are marked by two distinct seasons, a rainy season (October to April) and a dry season. The present study determined that Botryosphaeriaceae spp. spores were generally trapped from mid-fall to early spring, which corresponds to the rainy season. However, maximum numbers of Botryosphaeriaceae spores were recorded during the winter months of December, January, and February, when the majority of the precipitation occurs in the northern and southern regions of the state. A sporetrapping study was recently conducted in
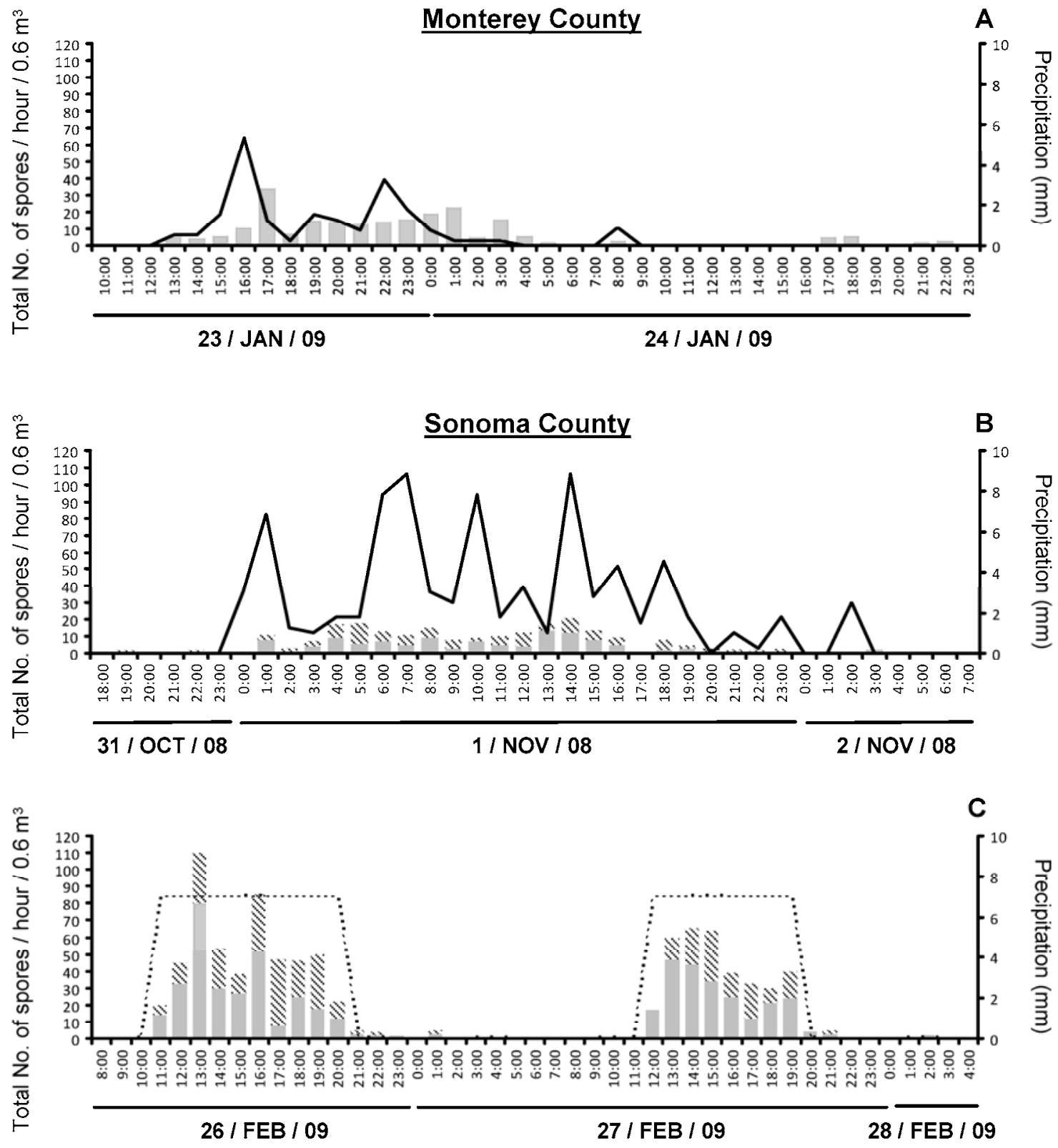

Diplodia spp. I Dothiorella spp.

Fig. 7. Rainfall and total number of Botryosphaeriaceae spores detected hourly in A, Monterey County from 10:00 A.M. on 23 January 2009 to 11:00 P.M. on 24 January 2009 and B, Sonoma County from 6:00 P.M. on 31 October 2009 to 7:00 A.M. on 2 November 2009. C, Botryosphaeriaceae spores detected during overhead sprinkler irrigation $\left(6.9 \mathrm{~mm} \mathrm{ha}^{-1} \mathrm{~h}^{-1}\right)$ in Sonoma County from 8:00 A.M. on 26 February 2009 to 4:00 A.M. on 28 February 2009. 
the Alsace grape-growing region in eastern France (8). As observed in our study, high numbers of Botryosphaeriaceae spores (specifically, D. seriata and D. mutila) were trapped in France during rain events. However, contrary to what was observed in our study, Botryosphaeriaceae spp. spores were mainly captured during the vegetative period (spring through fall) (8). Climatic conditions vary dramatically between California and the Alsace region of France, where the main rainy season occurs from spring to fall, and potentially explains the main differences observed in seasonal patterns of spore release.

Results of our study do confirm that, in addition to rainfall, overhead sprinkler irrigation can trigger Botryosphaeriaceae spp. spore release. This was particularly true in the vineyard site located in Riverside County (Indio, CA), where Botryosphaeriaceae spp. spores were trapped during each irrigation event. Indio is located at the southwestern end of the Coachella Valley, a table-grape production area characterized by its warm, dry climate, with less than $100 \mathrm{~mm}$ of annual precipitation and average daily temperatures of 21 and $38^{\circ} \mathrm{C}$ in winter and summer, respectively. Grapevines growing under these warm conditions year-round exhibit a different agronomic behavior than those growing in temperate climates (30). Table grape growers in the Coachella Valley practice earlywinter hydro-cooling with overhead sprinkler irrigation using a drip line (43). Although the irrigation schedule and amount of water applied varies between growers, sprinkling is generally carried out between 9:00 A.M. and 4:00 P.M. for approximately 45 days (1 November to mid-December) to 61 days (1 November to end of December) (43). Evaporative cooling of vineyards by sprinkler irrigation is also used in the Coachella Valley for leaching soil salinity in the rootzone (43). Consequently, we have shown that, even in a dry area where high spore release was not expected due to excessively low precipitation, the use of overhead irrigation was sufficient to trigger the release of Botryosphaeriaceae spp. spores. These results corroborate previous studies in which release and dissemination of $B$. dothidea pycnidiospores was reported to be primarily triggered by sprinkler irrigation in pistachio orchards throughout the San Joaquin Valley region in California (12). On the other hand, low numbers of Botryosphaeriaceae spp. spores were captured when sprinkler irrigation was used for frost protection in the Sonoma vineyard. Temperatures close to or below $0^{\circ} \mathrm{C}$ may limit Botryosphaeriaceae spp. spore release from pycnidia. However, the effect of freezing temperatures on Botryosphaeriaceae spp. spore release requires further investigation. Additionally, weather events such as snow and fog have been reported to induce release of Botryosphaeriaceae spp. spores in
France (8). Moreover, snow events can also trigger discharge of $E$. lata ascospores in Michigan and New York vineyards (17,31). Although release of Botryosphaeriaceae spp. spores in vineyards by means of snow is less likely under California weather conditions, fog could play a role in spore release, particularly in spring and summer in the coastal grape-growing areas. Results from our sites in Monterey and San Luis Obispo (Central Coast) showed slight captures of Botryosphaeriaceae spp. spores in summer, which could be a response to fog events in those areas. However, research would be necessary to categorically confirm that fog is associated with Botryosphaeriaceae spp. spore release in California vineyards.

Although there are similarities in seasonal patterns of species of Botryosphaeriaceae and E. lata in California, spore release timing coinciding with a rainfall or irrigation event differs between species of fungi. Botryosphaeriaceae spp. and E. lata both release spores shortly after the commencement of a rain or irrigation event (generally within $1 \mathrm{~h})(3,6,12)$. However, the end of the spore release period differs between these fungi; Botryosphaeriaceae spp. spores continued to be trapped within $2 \mathrm{~h}$ following the termination of rainfall or irrigation, whereas E. lata ascospores are reported to be released until drying of the stromata, which in some instances can require up to $36 \mathrm{~h}(3,6,17,33)$. E. lata ascospores are released within asci from perithecia buried in a stroma which are capable of continuous release while hydrated, even in the absence of rain $(3,32)$. Ascospores of E. lata are ejected into the air and disseminated by wind, and some studies have reported that they may travel up to $100 \mathrm{~km}$ from the inoculum source (21). Although the sexual stage of B. dothidea has been reported from giant sequoia (Sequoiadendron giganteum) and coastal redwoods (Sequoia sempervirens) in California (45), perithecia of Botryosphaeriaceae spp. have been rarely observed in perennial crops, including grapevines $(12,38,39)$. Therefore, the lack of species of Botryosphaeriaceae spores captured in our study shortly after the cessation of rainfall or irrigation may be a consequence of pycnidia and not perithecia as the main source of inoculum for Botryosphaeriaceae spp.

Under humid conditions, pycnidia of Botryosphaeriaceae spp. produce pycnidiospores that are generally exuded in a gelatinous matrix forming cirrhi, a ribbonlike mass of spores $(1,12,20,38)$. Consequently, once the impact of water droplets over pycnidia cease following the termination of rain or irrigation, Botryosphaeriaceae pycnidiospores may not be dispersed. Previous studies conducted in California pistachio orchards have confirmed $B$. dothidea to be a water-splashdispersed pathogen with relatively short distances of spore dispersal $(1,12)$. Consequently, although high relative humidity caused by a fog event, for example, could initiate sporulation in Botryosphaeriaceae spp. pycnidia, the impact of water droplets would be necessary for spore dispersal. In addition, there is a lack of information regarding the role that wind plays in dissemination of Botryosphaeriaceae spp. conidia, which may affect the distance of conidia dispersal. Moreover, studies have reported conidia of $B$. dothidea to also be disseminated by birds and insects in California pistachio orchards (12). Although birds, insects, and wind could be involved in dissemination of Botryosphaeriaceae spp. spores in vineyards, results from this and other studies $(1,12)$ indicate that Botryosphaeriaceae inoculum appears to be primarily splash dispersed. Therefore, because Botryosphaeriaceae spp. spores appear to be less airborne than those of $E$. lata, we hypothesize that relatively shortdistance dispersal also occurs in vineyards. Consequently, it is probable that most of the inoculum leading to new infections originates from within the same vineyard. Research in our laboratory is currently underway to investigate the role of natural ecosystems surrounding vineyards in the epidemiology of Botryosphaeriaceae spp.

Pruning of grapevines takes place during the dormant season, which in California coincides with the major rainfall period and, consequently, with the main fungal spore release period. Thus, highly susceptible infection sites are readily available to the fungi during this period. However, both spore trapping and pruning wound susceptibility studies have provided valuable information regarding periods of low risk of infection by E. lata, as well as management practices to minimize the risk of infection $(3,16,18,21)$. Successful disease management practices have been developed against eutypa dieback, which include pruning wound treatments $(22,28)$; late pruning (as close as possible to budbreak), when marked reduction of ascospore inoculum and more rapid wound healing occur $(6,16,21)$; and doublepruning, a practical technique to achieve late pruning in large vineyards (44). These strategies have resulted in significant reduction in pruning wound infection by $E$. lata in California. Accordingly, prevention of grapevine infections caused by Botryosphaeriaceae spp. may also depend on pruning wound protection with a fungicide and manipulation of the time of pruning. Manipulation of both the time of pruning and of sprinkler irrigation could greatly reduce pruning wound infections by Botryosphaeriaceae spp. in dry regions such as the Coachella Valley, where fewer precipitation events typically occur. Based on the overall results of this study, pruning grapevines in California from midDecember to mid-February could be particularly risky because of the high prob- 
ability of rain and subsequent high Botryosphaeriaceae spp. spore release. An important reduction of Botryosphaeriaceae spp. spores was generally observed in late winter and early spring throughout the course of this study, due to decreased rainfall; this suggests that pruning during this period would likely decrease the risk of infection. Because late pruning is not always feasible, mostly in large-acreage vineyards, a fungicide or a biological control application directly on the wounds at the time of pruning may enhance disease control.

The work presented here emphasizes the importance that spore-trapping studies have in understanding the epidemiology of Botryosphaeriaceae spp. in California vineyards and provides valuable information regarding the characterization of lowrisk infection periods that could be used by growers to improve disease control by alteration in the pruning timing.

\section{ACKNOWLEDGMENTS}

This research was founded by the California Competitive Grant Program for Research in Viticulture and Enology, American Vineyard Foundation, and Viticulture Consortium West. We thank D. Miltz and S. Montez (Farm Advisor Assistants, Monterey County), A. Breschini (Farm Advisor Assistant San Luis Obispo County), J. Nosera, P. Papper, and S. Baker (Farm Advisor Assistants, Mendocino County), Y. Rasmussen (Farm Advisor Assistant, Napa County), M. Hannosh (Farm Advisor Assistant, Riverside County), and J. Yeo (Farm Advisor Assistant, Sonoma County) for their valuable field assistance; and the reviewers for their valuable comments and suggestions, which significantly improved the quality of this manuscript.

\section{LITERATURE CITED}

1. Ahimera, N., Gisler, S., Morgan, D. P., and Michailides, T. J. 2004. Effects of single-drop impactions and natural and simulated rains on the dispersal of Botryosphaeria dothidea conidia. Phytopathology 94:1189-1197.

2. Barr, M. E. 1972. Preliminary studies on the Dothideales in temperate North America. Contrib. Univ. Mich. Herbarium 9:523-638.

3. Carter, M. V. 1991. The status of Eutypa lata as a pathogen. International Mycological Institute, Phytopathological Paper 32. CAB International, Wallingford, England.

4. Castillo-Pando, M., Somers, A., Green, C. D., Priest, M., and Sriskanthades, M. 2001. Fungi associated with dieback of Semillon grapevines in the Hunter Valley of New South Wales. Aust. Plant Pathol. 30:59-63.

5. Eskalen, A., and Gubler, W. D. 2001. Association of spores of Phaeomoniella chlamydospora, Phaeoacremonium inflatipes, and Pm. aleophilum with grapevine cordons in California. Phytopathol. Mediterr. 40:429-432.

6. Gubler, W. D., Rolshausen, P. E., Trouillas, F. P., Urbez-Torres, J. R., Voegel, T., Leavitt, G. M., and Weber, E. A. 2005. Grapevine trunk diseases in California. Pract. Winery Vineyard (Jan/Feb):6-25

7. Hewitt, R. W. B. 1988. Diplodia cane dieback and bunch rot. Pages 25-26 in: Compendium of Grape Diseases. American Phytopathological Society Press, St. Paul, MN.

8. Kuntzmann, P., Villaume, S., and Bertsch, C.
2009. Conidia dispersal of Diplodia species in a French vineyard. Phytopathol. Mediterr. 48:150-154.

9. Latorre, B. A., Besoaín, X., and Flores, V. 1986. Botryosphaeria canker of table grapes. (Abstr.) Phytopathology 76:1112.

10. Leavitt, G. M. 1990. The occurrence, distribution, effects and control of Botryodiplodia theobromae on Vitis vinifera in California, Arizona and northern Mexico. Ph.D. dissertation, University of California, Riverside.

11. Lehoczky, J. 1988. Black dead arm. Page 35 in: Compendium of Grape Diseases. American Phytopathological Society Press, St. Paul, MN.

12. Michailides, T. J., and Morgan, D. P. 1993. Spore release by Botryosphaeria dothidea in pistachio orchards and disease control by altering the trajectory angle of sprinklers. Phytopathology 83:145-152.

13. Milholland, R. D. 1988. Macrophoma rot. In: Compendium of Grape Diseases. American Phytopathological Society Press, St. Paul, MN.

14. Moller, W. J., and Carter, M. V. 1965. Production and dispersal of ascospores in Eutypa armeniacae. Aust. J. Biol. Sci. 18:67-80.

15. Moller, W. J., and Kasimatis, A. N. 1978. Dieback of grapevines caused by Eutypa armeniacae. Plant Dis. 62:254-258.

16. Munkvold, G. P., and Marois, J. J. 1995. Factors associated with variation in susceptibility of grapevine pruning wounds to infection by Eutypa lata. Phytopathology 85:249-256.

17. Pearson, R. C. 1980. Discharge of ascospores of Eutypa armeniacae in New York. Plant Dis. 64:171-174.

18. Petzoldt, C. H., Sall, M. A., and Moller, W. J. 1983. Factors determining the relative number of ascospores released by Eutypa armeniacae in California. Plant Dis. 67:857-860.

19. Phillips, A. J. L. 1998. Botryosphaeria dothidea and other fungi associated with excoriose and dieback of grapevines in Portugal. J. Phytopathol. 146:327-332.

20. Phillips, A. J. L. 2002. Botryosphaeria species associated with diseases of grapevines in Portugal. Phytopathol. Mediterr. 41:3-18.

21. Ramos, D. E., Moller, W. J., and English, H. 1975. Production and dispersal of ascospores of Eutypa armeniacae in California. Phytopathology 65:1364-1371.

22. Rolshausen, P. E., and Gubler, W. D. 2005. Use of boron for the control of Eutypa dieback of grapevines. Plant Dis. 89: 734-738.

23. Rolshausen, P. E., and Wilcox, W. 2009. Identifying the causes of wood cankers and branch dieback in eastern U. S. vineyards. Phytopathol. Mediterr. 48:164.

24. Rooney-Latham, S., Eskalen, A., and Gubler, W. D. 2005. Occurrence of Togninia minima perithecia in esca-affected vineyards in California. Plant Dis. 89:867-871.

25. Scheck, H., Vasquez, S., Fogle, D., and Gubler, W. D. 1998. Three Phaeoacremonium spp. cause young grapevine decline in California. Plant Dis. 82:590.

26. Siebert, J. B. 2001. Eutypa: The economic toll on vineyards. Wines Vines April:50-56.

27. Slippers, B., and Wingfield, M. J. 2007. Botryosphaeriaceae as endophytes and latent pathogens of woody plants: diversity, ecology and impact. Fungal Biol. Rev. 21:90-109.

28. Sosnowski, M. R., Creaser, M. L., Wicks, T. J., Lardner, R., and Scott, E. S. 2008. Protection of grapevine pruning wounds from infection by Eutypa lata. Aust. J. Grape Wine Res. 14:134-142.

29. Taylor, A., Hardy, G. E. St. J., Wood, P., and Burgess, T. 2005. Identification and pathogenicity of Botryosphaeria species associated with grapevine decline in Western Australia. Aust. Plant Pathol. 34:187-195.

30. Teixeira, A. H. de C., Bastiaanssen, W. G. M., and Bassoi, L. H. 2007. Crop water parameters of irrigated wine and table grapes to support water productivity analysis in the Sao Francisco river basin, Brazil. Agric. Water Manage. 94:31-42.

31. Trese, A. T., Burton, C. L., and Ramsdell, D. C. 1980. Eutypa armeniacae in Michigan vineyards: Ascospore production and survival, host infection, and fungal growth at low temperatures. Phytopathology 70:788-793.

32. Trouillas, F. P., and Gubler W. D. 2004. Identification and characterization of Eutypa leptoplaca, a new pathogen of grapevine in Northern California. Mycol. Res. 108:1195-1204.

33. Trouillas, F. P., and Gubler W. D. 2009. The status of Eutypa lata in California. Phytopathol. Mediterr. 48:161-162.

34. Úrbez-Torres, J.R., Adams, P., Kamas, J., and Gubler, W.D. 2009. Identification, incidence, and pathogenicity of fungal species associated with grapevine dieback in Texas. Am. J. Enol. Vitic. 60:497-507.

35. Úrbez-Torres, J. R., and Gubler, W. D. 2009. Pathogenicity of Botryosphaeriaceae species isolated from grapevine cankers in California. Plant Dis. 93:584-592.

36. Úrbez-Torres, J. R., Leavitt, G. M., Guerrero, J. C., Guevara, J., and Gubler, W. D. 2008. Identification and pathogenicity of Lasiodiplodia theobromae and Diplodia seriata, the causal agents of bot canker disease of grapevines in Mexico. Plant Dis. 92:519-529.

37. Úrbez-Torres, J. R., Leavitt, G. M., Guerrero, J. C., Guevara, J., Striegler, K., Allen, A., and Gubler, W. D. 2007. Identification of fungal pathogens associated with grapevine cankers in the main grape-growing areas of the United States and Mexico. Phytopathol. Mediterr. 46:109-110

38. Úrbez-Torres, J. R., Leavitt, G. M., Voegel, T., and Gubler W. D. 2006. Identification and distribution of Botryosphaeria species associated with grapevines cankers in California. Plant Dis. 90:1490-1503.

39. Úrbez-Torres, J. R., Luque, J., and Gubler, W. D. 2007. First report of Botryosphaeria iberica and $B$. viticola associated with grapevine decline in California. Plant Dis. 91:772.

40. Úrbez-Torres, J. R., Peláez, H., Santiago, Y., Martín, C., Moreno, C., and Gubler, W. D. 2006. Occurrence of Botryosphaeria obtusa, $B$. dothidea and $B$. parva associated with grapevine trunk diseases in Castilla y León region, Spain. Plant Dis. 90:835.

41. van Niekerk, J. M., Crous, P. W., Groenewald, J. Z., Fourie, P. H., and Halleen, F. 2004. DNA phylogeny, morphology and pathogenicity of Botryosphaeria species on grapevines. Mycologia 96:781-798.

42. von Arx, J. A. 1987. Plant pathogenic fungi. Nova Hedwigia 87:288.

43. Wallender, W. W., Tanji, K. K., Clark, B., Hill, R. W., Stegman, E. C., Gilley, J. R., Lord, J. M., and Robinson, R. R. 2007. Drip irrigation water and salt flow model for table grapes in Coachella Valley, California. Irrig. Drain. Syst. 21:79-95.

44. Weber, E. A., Trouillas, F. P., and Gubler, W. D. 2007. Double-pruning of grapevine: a cultural practice to reduce infection by Eutypa lata. Am. J. Enol. Vitic. 58:61-66.

45. Worral, J. J., Correll, J. C., and McCain, A. H 1986. Pathogenicity and teleomorph-anamorph connection of Botryosphaeria dothidea on Sequoiadendron giganteum and Sequoia sempervirens. Plant Dis. 70:757-759. 